\title{
THE PRINCIPLE OF DISCLOSURE OF CREATIVE ABILITIES OF STUDENTS IN TRAINING A FOREIGN LANGUAGE Menlashev M.T. ${ }^{1}$, Malykhina L.Sh. ${ }^{2}$ (Republic of Tajikistan) Email: Menlashev343@scientifictext.ru
}

\author{
${ }^{I}$ Menlashev Mukhamedkarim Temirbulatovich - Candidate of Pedagogical Sciences, \\ Associate Professor; \\ ${ }^{2}$ Malykhina Laily Shakhimardonovna - Candidate of Philological Sciences, Associate Professor, Head, \\ ENGLISH DEPARTMENT (INTERFACULTY), \\ TAJIK-RUSSIAN SLAVONIC UNIVERSITY, \\ DUSHANBE, REPUBLIC OF TAJIKISTAN
}

\begin{abstract}
: the article deals with considering the principle of disclosure of creative abilities of students when training a foreign language. Process to increase the motivation of educational activity of students proceeds more effectively during creation favorable psychological climate at which each student is busy with performance of certain tasks, the teacher helps to study i.e. directs the student to eliminate certain problems with vocabulary or the translation, pays attention and comes to the rescue students with law level of knowledge, gives the feasible tasks them to feel confidence and success. Prevention of mental tension, the principle of goodwill, professionally official style of communication, encouragement as additional motivation in the emotional plan, development and demonstration of the video presentations all this is an effective factor in disclosure of abilities of students at learning a foreign language.
\end{abstract}

Keywords: motivation, creative abilities, transformation, didactic tasks, creativity, activity, internal motivation, video presentation.

\section{ПРИНЦИП РАСКРЫТИЯ ТВОРЧЕСКИХ СПОСОБНОСТЕЙ СТУДЕНТОВ ПРИ ОБУЧЕНИИ ИНОСТРАННОМУ ЯЗЫКУ Менлашев М.Т.1, Малыхина Л.Ш.' (Республика Таджикистан)}

\author{
${ }^{1}$ Менлашев Мухамедкарим Темирбулатович - кандидат педагогических наук, дочент; \\ ${ }^{2}$ Малыхина Лайли Шахимардоновна - кандидат педагогических наук, доцент, заведующая кафедрой, \\ кафедра английского языка (межфакультетская), \\ Российско-Таджикский Славянский университет, \\ г. Душанбе, Республика Таджикистан
}

\begin{abstract}
Аннотация: в статье речь идет о принципе раскрытия творческих способностей студентов при обучении иностранному языку. Процесс повышения мотивации учебной деятельности студентов протекает более эффективно при создании благоприятного психологического климата, при котором каждый студент занят выполнением определенных заданий, преподаватель помогает учиться, т.е. направляет студента на устранение возникиих определенных проблем с лексикой или переводом, оказывает внимание и приходит на помощь студентам, отстающим по уровню знания от других студентов, дает посильные задания, вселяющче чувство уверенности и успеха. Профилактика психической напряженности, принщип доброжелательности, профессионально-деловой стиль общения на иностранном языке, поощрение как дополнительная мотивации в эмоциональном плане, разработка и демонстрация видеопрезентаций все это является действенным фактором в раскрытии способностей студентов при изучении иностранного языка.
\end{abstract}

Ключевые слова: мотивачия, творческие способности, трансформация, дидактические задачи, креативность, деятельность, внутренняя мотивация, видеопрезентация.

Поистине недостаточно проводятся мероприятия воспитательного характера, направленные на проявление любви к иностранному языку. Действительно иностранный язык не является столь популярным предметом, начиная со школы, он не стал смыслом жизни определенной части молодых людей, не стал обязательной нормой из-за отсутствия внутренней мотивации.

Однако эпоха глобализации оказывает большое влияние на социально-экономические отношения, происходящие во многих странах, в том числе в Таджикистане. В связи с этим появилась потребность в высоквалифицированном специалисте, как самостоятельной, творческой личности, готовой к решению нестандартных социальных и жизненных ситуаций, уверенной в своих знаниях и в своих возможностях.

Кардинальная трансформация общественных ценностей в сфере деятельности привела к тому, что личность становится все более зависимой от социального контекста. Общественные нормы и установки становятся доминирующими при выборе профессии, при реализации человека в ней и достижении определенных результатов [1]. 
Сегодня обществу нужны специалисты с креативным и творческим уклоном, самостоятельно принимающие ответственные решения в ситуации выбора, отличающиеся мобильностью, динамизмом и конструктивностью

На современном этапе социально-психологический подход к изучению мотивации к иностранному языку определяет взаимосвязь личностного и социального контекстов деятельности в процессе овладения студентами иностранным языком.

Для решения поставленных дидактических задач необходимо создание благоприятного психологического климата, способствующая правильной организованной деятельности в рамках основного педагогического процесса, ведущая к повышению эффективности как отдельных его составляющих, так и процесса в целом.

Процесс повышения мотивации учебной деятельности студентов протекает более эффективно, если:

a) в создана рабочая атмосфера, где каждый студент занят выполнением определенных заданий,

б) преподаватель не учит, а помогает учиться т.е. направляет студента на устранение возникших определенных проблем с лексикой или переводом,

в) оказывает внимание и приходит на помощь студентам, которые отстают по уровню знания от других студентов,

г) преподаватель дает посильные задания, при выполнении которых студент чувствует уверенность.

В комплексе психолого-педагогических приемов, содействующих мотивации учебной деятельности студентов необходимо постоянное внимание профилактике психической напряженности, которая забирает огромное количество энергии как преподавателя так и студента.

Весьма важным моментом при обучении является стиль общения со студентами, которые представляют выполнение заданий, как работу в некой фирме, получая за это реальные баллы в рамках кредитно-рейтинговой системы. При такой системе организации труда они ясно и четко представляют, что задачи, поставленные перед ними, выполнимы, что это способствует внутреннему стимулированию и ощущению радости в умении работать с иноязычным материалом в эмоциональном плане.

Одним из действенных факторов в психологическом плане является принцип доброжелательности, с помощью которой преподаватель располагает к себе всю аудиторию, в которой находятся студенты с различным уровнем знаний и отношением к иностранному языку с мотивационной точки зрения. Не менее важным являются произнесение фразы, что «английский язык очень легкий для изучения», в котором нет склонений, глагольного вида, окончаний и для его освоения нужно понять правила грамматики. Все это воспитывает в студентах чувство оптимизма и уверенности, формирует в них реалистический дух.

Как отмечают Л.М Даукша, Л.В. Чекель, результативость обучения становится невозможной без желания учится, без хорошего уровня мотивации учащихся. Учебная мотивация психофизиологический процесс, включающий коммуникативно-познавательную потребность субъекта на фоне его общей потребности достижения и определяющий направленность поведения данного субъекта, его активность, организованность и устойчивость [2, 9].

Любому студенту, вне зависимости от его уровня знания, важно поощрение в ходе обучения в виде баллов, способствующих созданию дополнительной мотивации в эмоциональном плане и желания выполнять дальнейшие задания с рабочим настроением. Хорошим стимулом в развитии творческих способностей студентов является разработка и демонстрация видеопрезентаций по учебному материалу с использованием видео, музыкального сопровождения, картинок, схем, таблиц.

В этом плане преподаватель тщательно объясняет как надо правильно использовать лексический и грамматический материал для создания видеопрезентаций, где наглядность должна гармонировать с лаконичным текстовым материалом и музыкальным сопровождением. Нельзя подвергать критике студента за неудачно собранный материал по видеопрезентации, а наоборот на наглядном примере надо научить студента умению редактировать имеющийся материал. Такая работа со стороны преподавателя заслуживает уважения именно в мотивационном плане, так как студент впервые приступает к творческому осмыслению информационного материала с использованием компьютерных технологий.

Опыт работы показал, что к концу учебного в РТСУ на отделении немецкого и китайского языков не осталось неуспевающих студентов благодаря целенаправленной и правильно поставленной работе с методической точки зрения.

На кафедре английского языка межфак РТСУ студентами этих групп был собран богатый учебный материал в виде презентаций по лексике, грамматике и домашнему чтению в специальной электронной библиотеке кафедры, который оказал неоценимую помощь для последующих групп в методическом плане. Тематика презентаций обширна:1) грамматические таблицы образования времен Continuous, 2) Passive Voice, 3) Gerund, 4) Сомерсет Моэм, 5) королева Англии, 6)полиглоты 7) Марк Твен, 8) Лоуренс Оливье и т.д. 
Видеопрезентации является абсолютно новым заданием, которое прежде не выполнялось в школе, где уровень использования компьютерных технологий не достиг еще своего предела и домашние задания по предметам не ориентированы на использование компьютера.

Развитие коммуникативной компетенции при обучении иностранному языку будет способствовать раскрытию личности студента в межкультурной коммуникации, дальнейшему самосовершенствованию и самообразованию при ярко выраженной мотивации к иностранному языку, целенаправленная на активность и выбор средств и приемов.

С целью повышения мотивации к овладению иностранными языками могут быть задания на неподготовленную речь. Преподаватель называет имя студента, и он должен сразу говорить на иностранном языке на любую тему (в трех, пяти и более предложениях), если студент не может собраться, надо начать спрашивать другого, а первому дать время подумать. В итоге какая-то часть студентов не справится с данным заданием. Это не трагедия, не надо добиваться 100\% выполнения, урок за уроком данные студенты проявят склонность к выполнению таких заданий и проблема решится.

Неподготовленная речь начинает стимулировать речемыслительную деятельность студента, происходит процесс включения мозга, памяти в один из сложнейших процессов говорения, порождения речи на иностранном языке. Такое задание настолько свободно в творческом плане, что перед студентами стоит огромный выбор тем, к выполнению которых они мобилизуют весь прошлый опыт знания по иностранному языку.

Пример одного из таких занятий на отделении немецкого языка РТСУ. Один из студентов рассказал об истории шариковой ручки, которой пользуется весь мир вместо чернильной авторучки, она была изобретена венгерским журналистом Ласло Биро (венг. László József Bíró) в 1931 году, он жил в Аргентине и его ручки называют «биромами». Другая студентка рассказала, что потерянные вещи надо звать и они действительно находятся. Третий из числа студентов отказался от задания и предложил спеть песню на английском, овациям не было конца. Следующий студент рассказал, что королева Англии Елизавета II, несмотря на преклонный возраст, работает, не покладая рук. Столько было неожиданности в данном задании, что студенты полностью отвлеклись от всех психологических барьеров, если кому-то не хватало слов, аудитория дружно подсказывала слова, дабы не сорвать нетрадиционный вид работы, в котором столько интереса и эмоций.

Студенты активно работают на протяжении всего учебного года, преодолевая все свои внутренние противоречия на начальном этапе обучения, и как отмечает подавляющее большинство студентов, что изменив свое отношение к иностранному языку и пробудив свою внутреннюю мотивацию, они испытывали ощущение «внутреннего покоя» и задумывались о своем самообразовании в дальнейшем.

\section{Список литературы / References}

1. Буянова М.В. Социально-психологические факторы мотивации достижения: Дис. канд. психол. наук: 19.00.05: СПб., 2004, 179 с. [Электронный pecypc]. Режим доступа: http://naukapedagogika.com/psihologiya-19-00-05/dissertaciya-sotsialno-psihologicheskie-faktory-motivatsiidostizheniya/ (дата обращения: 05.08.2018).

2. Даукша Л.М. Чекель Л.В. Педагогическая психология. Учебно-методический комплекс по одноименному курсу для студ./Л.М. Даукша, Л.В. Чекель. Учреждение образования «Гродненский гос. ун-т им. Я.Купалы». Гродно: ГрГУ, 2008. 471 с. ISBN 978-985-515-054-2. 